\title{
Satellite Images Applied to Assess the Influence of Amazon River Seasonal Dynamic on the Floodplain Lake Morphology
}

\author{
Andreia M. S. França1, Teresa G. Florenzano², Evlyn M. L. M. Novo² \\ ${ }^{1}$ Instituto Federal de Brasília, Campus Samambaia, Brasilia, Brazil \\ ${ }^{2}$ Instituto Nacional de Pesquisas Espaciais, Divisão de Sensoriamento Remoto, São José dos Campos, Brazil \\ Email: andreia.franca@ifb.edu.br
}

Received 20 July 2014; revised 20 August 2014; accepted 4 September 2014

Copyright $@ 2014$ by authors and Scientific Research Publishing Inc.

This work is licensed under the Creative Commons Attribution International License (CC BY).

http://creativecommons.org/licenses/by/4.0/

(c) (i) Open Access

\begin{abstract}
The objective of this study is to assess the influence of the Amazon River seasonal dynamic on floodplain lake morphology. The study area includes the Amazon River floodplain reach encompassed by the Madeira and Tapajós River confluences. Products from the Global Rain Forest Mapping (GRFM) and Moderate Resolution Imaging Spectroradiometer (MODIS) were used to derive variables such as lake size, shape and number. The main steps in the research were: data base implementation, legend definition, image processing (merge, segmentation, classification and edition), morphological mapping and quantitative assessment. Four classes of lacustrine morphology were defined in this study: circular/elliptical, elongated, composite, and dendritic. The result showed that 1) the lake class increased $18.38 \%$ from the low- to high-water period; 2) there was a reduction in the total number of lakes from low to high water; 3 ) the most common lake type was the circular/elliptical; and 4) better results were obtained integrating SAR and optical sensors.
\end{abstract}

\section{Keywords}

Amazon River Floodplain, Seasonal Dynamic, Morphological Lakes, Remote Sensing, SAR-JERS-1/GRFM, MOD09-TERRA

\section{Introduction}

The geomorphology of floodplains is characterized by a variety of terrain shapes, such as scroll bars, overbank 
deposits, lakes, lake deposits, and channels which are constantly changing in response to the present hydrology and depositional and erosion history of the basin [1]. Despite the controversies that surround the Amazon Basin's geologic history [2], there is a certain degree of consensus that the floodplain geomorphology of the Amazon River, and its main tributaries, respond to tectonic and climatic forcing [3] [4] that have been in place since the late Pleistocene and Holocene periods.

The tectonic control is linked to trends in the drainage pattern formed by some Amazon tributaries, the NESW and NW-SE trends. This pattern was observed in the entire Amazon/Solimões floodplain [5]-[8]. Recently [9] reported that the analysis of the digital elevation model derived from Shuttle Radar Topographic Mission (SRTM) data revealed a large paleo drainage system. This paleo system supports the idea that the Rio Negro's present lower course is the result of what the authors call a mega-fluvial capture driven by the prevalent active tectonic regime in the Amazon Basin. Other important structural components with E-W and nearly N-S directions were also reported [10], indicating intense neo-tectonic activity in the basin.

Floodplain geomorphology is also related to climate changes and fluctuations in the eustatic sea level during the Quaternary. These fluctuations support the hypothesis that during the stabilization of the sea-level about six thousand years ago, mouths of the tributaries of the Amazon River were drowned giving rise to the rias [11].

At present, this floodplain is actively reshaped by the Amazon River and its tributaries, which transfer an estimated sediment load of 1200 tons/year through it. The Amazon/Solimões River mainstem receives water with high sediment content from the Andes, which is responsible for much of this sediment load. Floods are a dominant factor in the development of floodplain topography. In aggrading rivers, such as the Solimões/Amazon, flood characteristics such as frequency, flow velocity, hydro-period and concentration, and settling characteristics of the load are responsible for the floodplain sediment's final destination.

The Solimões/Amazon River floodplain is characterized by a large number of lakes of different shapes and sizes. Reference [12], surveying an area of $92,300 \mathrm{~km}^{2}$ of the Amazon River mainstem, found 6510 lakes of at least $100 \mathrm{~m}$ in length. The thousands of floodplain lakes in the central Amazon Basin vary considerably in shape (circular to dendritic) and size (100 $\mathrm{m}$ to $50 \mathrm{~km}$ long). Reference [13] identified representative floodplain types in the Amazon using the lake shape and size as criteria for classification. The author identified a wide, scroll-bar floodplain with long, narrow lakes and a smooth surfaced floodplain with huge, multi-input, shallow lakes. In the upstream reaches, sediment deposition in and migration of floodplain channels has erased (or continually erases) main-channel oxbow lakes and yields an intricate scroll-bar topography that forms the boundaries of hundreds of long, narrow lakes. In contrast, downstream reaches are characterized by channels restricted by stabilizing, long-term levee building, and floodplain construction dominated by overbank deposition. Overbank deposition buries the scroll-bar topography, resulting in a flat floodplain covered by a patchwork of large, and more equated and shallow lakes [1].

Recently [3], studying a region near the Negro-Solimões confluence, identified three geomorphological and sedimentological units in the floodplain - an older scroll-dominated plain, an impeded floodplain, and a channel-dominated floodplain, which have included an abandoned alluvial. The impeded unit, according to the authors, is characterized by a number of round or irregularly shaped lakes on a very flat surface. However, the shape and size of lakes are also key elements for the identification and characterization of geomorphological and sedimentological units in floodplains.

Taking into account the fact that the lake morphology is a complex response to the ancient and present response of the floodplain to the tectonic, climatic, and hydrologic factors, it is very important to assess changes in lake morphology both in response to the flood pulse and along different floodplain reaches. This is important, not only because of the large number of lakes in the floodplain, but also because lakes can be used as a key variable for understanding aquatic system functions. According to [14], lake fetch affects wind-effected vertical mixing and concomitant differences in stratification and perhaps productivity. Lake shape also affects the nutrient exchanges between the aquatic and terrestrial ecosystem. The larger the lake shoreline, the more intense the nutrient exchange between terrestrial and aquatic ecosystems.

Lake morphology is therefore a first approach to the classification of the floodplain lake system. Although only a few of the floodplain lakes have been studied intensively, they are known to vary considerably in their limnological features and much of this variation is probably caused by differences not only in the present lake morphology, but also in its geomorphologic history.

Analysis of the abundance, distribution, and morphology of Amazon floodplain lakes is of interest from a 
limnological and geomorphological perspective, and provides information that is relevant to the management of floodplain ecosystems [15]. Improved estimates of wetland area are important for assessing habitat availability, managing fish and timber stocks, and estimating regional methane fluxes to the troposphere [8]. Recent studies [16] also suggest that floodplain lake morphology variables such as size, shape and connectivity might be important to the understanding of aquatic mammals' migration patterns.

Remote sensing techniques are a powerful tool for studying lake morphology in isolated, inaccessible and large areas such as the Amazon floodplain. The synoptic view and multi-date images provide information not available otherwise. In spite of this, the Amazon Basin's frequent cloud cover and marked seasonal variation are a challenge to remote sensing of ecological characteristics of open waters and floodplain vegetation [15].

Low-resolution optic sensors with daily global coverage, such as MODIS, can provide synoptic coverage although cloud cover constrains their utility. Active SAR systems, which are much less influenced by clouds and smoke and are able to penetrate vegetation at some wavelengths, have great potential for mapping open water and wetlands. SAR data also provide excellent vegetation/water discrimination [17].

In this study therefore, we investigate the synergy between optical and SAR data in order to evaluate the influence of the Amazon River seasonal dynamic on the lake morphology. To carry out the study we selected a floodplain reach encompassing a variety of lake shapes and sizes. This region covers the stretch of the Amazon River floodplain which ranges from the Amazon-Madeira River confluence to the Amazonas-Tapajós confluence.

\section{The Study Area}

The reach of the Amazon River examined in this paper extends nearly $550 \mathrm{~km}$ from the Amazon's Madeira River confluence down to the Amazon's Tapajós confluence, between $01^{\circ} 20^{\prime}$ and $04^{\circ} 00^{\prime}$ South and between $59^{\circ} 00^{\prime}$ and $54^{\circ} 25^{\prime}$ West (Figure 1). Covered by tropical rain forest, the study area is located in the east central part of the Amazonas Sedimentary Basin. Its sedimentary pile ranging from Ordovician to Tertiary in age, are covered by alluvial deposits [9] [18]. Basement crustal blocks, consolidated during the Early Proterozoic form the Ventuari-Tapajós Geochronological Province, lie in a prominent NW-SE trend [19]. Major regional faults limiting these basement blocks are rejuvenated by an active neotectonics, confirmed by seismographic records obtained in the Amazônia [20]. The witness of a regional tectonic activity influencing the courses of several drainage streams in central Amazônia was confirmed by many studies, using many different methods and data [5] [20] [21].

The fluvial plain of the Amazon River consists of a complex system of Quaternary sedimentary units of different ages and formation conditions. The present position of channel as well as the morphology and size of the alluvial plain are related to neotectonic lineaments [3]. According to those authors, remote sensing data indicates that besides the predominant NE-SW and NW-SE lineaments, verified by [5], in studies regarding the middle Amazon, the N-S to NNE-SSW and E-W to ENE-WSW trends control the location and appearance of the alluvian plain. Reference [21], observed that as general rule, the alluvial plain was broadest where the river crosses faulted sunken tectonic blocks. The sunken blocks are trapezoidal or V-shaped and generally elongate toward NW and NE.

This study area lies between Quaternary and Tertiary deposits, which are unconsolidated fluvial and lacustrine deposits, and the Tertiary Barreiras Formation consisting of unconsolidated sands, silts and clays, with scattered conglomerate lenses and crude stratification. The Quaternary and Tertiary deposits for terraces are $10-15 \mathrm{~m}$ higher than the surface of the alluvial plain [22].

The Madeira River, an Andean affluent, reaches the Amazon with a very large sediment load which is responsible for intense floodplain sedimentation. The Tapajós River has a much lower sediment load. Data collected in the main stem of the Amazon River showed that the amount of suspended particles in white water, such as the Madeira River, was almost 15 times greater than that of clear water. The study area encompasses, therefore, a large variety of lake sizes and shapes which are representative of the eastern Amazon River floodplain and for this reason was chosen for study. Besides that, the study region shows a dominance of large lakes which facilitate analysis through JERS mosaics. Another reason why this area was selected is because it is a representative area that concentrates all of the water types according to the typology [23]: the Madeira river (white water), Tapajós river (clear water), and Urubu and Trombetas rivers (black water). Also, this area is understudied, as most studies concentrate on the Manaus reach. 


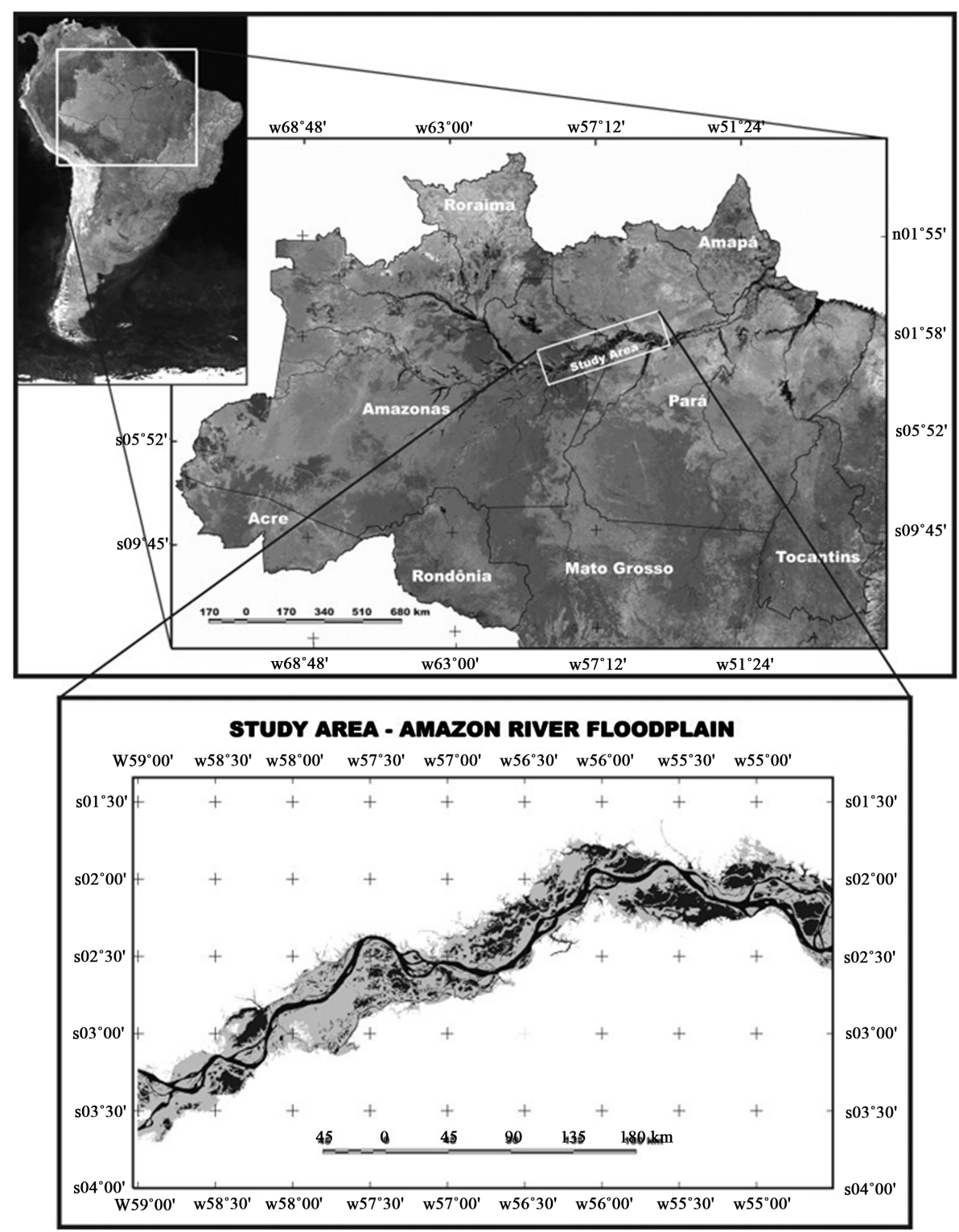

Figure 1. Study area-Amazon River floodplain.

\section{Materials and Methods}

The following data sets were used to carry out this study: 1) the Global Rain Forest Mapping (GRFM) Project mosaics of JERS-1 (Japanese Earth Resources Satellite) SAR data at $100 \mathrm{~m}$ resolution (Table 1) acquired at low and high water as described by [24]. The GRFM data sets were acquired timed to low- and high-water stages of the Amazon River [24] [25]; 2) Terra/MODIS (Moderate Resolution Imaging Spectroradiometer) images were also timed to low-water and high-water stages (Table 2).

Synthetic Aperture Radar (SAR) sensors are useful for remote sensing of tropical wetlands, because they penetrate cloud cover and can detect flooding beneath vegetation canopies. The L-band frequency and HH (horizontal send, horizontal receive) polarization of the JERS-1 image mosaics are therefore useful for mapping floodplain environments at regional scales.

The Moderate Resolution Imaging Spectroradiometer (MODIS) is a key instrument on board of both the EOS Terra (launched in December 1999) and the EOS Aqua satellites (launched in 2002). In the present study we used the Land products which were available at $250 \mathrm{~m}$ by $250 \mathrm{~m}$ resolution in two wavebands as day product, since the image date had to be at a similar Amazon River water level as that acquired in the SAR data. MODIS 
Table 1. Data characteristics of GRFM/JERS-1.

\begin{tabular}{ccccc}
\hline Acquisition & Period & Frequency and Polarization & Incidence Angle Range & Resolution \\
\hline August-September 1995 & Low-water & L/HH & $34^{\circ}-43^{\circ}$ & $100 \mathrm{~m}$ \\
May-August 1996 & High-water & L/HH & $34^{\circ}-43^{\circ}$ & $100 \mathrm{~m}$ \\
\hline
\end{tabular}

Table 2. Data characteristics of Terra/MODIS.

\begin{tabular}{ccccc}
\hline Acquisition & Period & Tile & Bands & Resolution \\
\hline September 2001 & Low-water & H12V9 & Red (1) Near Infrared (2) & 250 m \\
August 2001 & High-water & H12V9 & Red (1) Near Infrared (2) & 250 m
\end{tabular}

acquisition was also aimed to Nadir view data over the study area to avoid geometric effects derived from oblique view. Because lake size and shape were variables of interest, the Nadir viewing images were the most adequate for this task.

Stage data provided by the ANEEL Hidro Website (http://hidroweb.aneel.gov.br) from the years 1995 and 1996 (GRFM mosaic image acquisition) and 2000 to 2003 (MODIS image acquisition) were analysed so as to match all data available in relation to common river stages. Data from two gauging stations of the study area, Óbidos and Parintins, were analysed to account for spatial variation in river stages. Stage statistics (mean and variance) were computed for both time series (1995-1996 and 2000-2003) allowing the identification of the most suitable MODIS images to be merged to the JERS-1 mosaics.

All the images (SAR and MODIS) were integrated into a database and analyzed by means of the SPRING (Sistema de Processamento de Informações Georeferenciada) and IDRISI Kilimanjaro software.

The main steps in the study were: database implementation, legend definition, image processing (merge, segmentation, classification and edition), morphological mapping, and quantitative assessment. After a preliminary image processing, a ground truth mission was carried out on the LagoCuruai test-site, in February of 2004. This mission allowed recording of 103 GPS coordinates of sampling points with the description of local geomorphologic features, which were subsequently used to interpret the remaining scenes.

The first step in the image processing was to create a data base with both SAR/JERS-1 and MODIS images for each season: low water and high water, in order to generate multi-sensor color composite assigning colors to different sensor bands. Green was assigned to L-band; red and blue were assigned to MODIS bands 1 and 2, respectively. MODIS images were also resampled to $100 \mathrm{~m} \times 100 \mathrm{~m}$ pixel size.

After creating this database, the wetland mask provided by [24] was used as a tool for limiting image processing to the floodplain region. This mask, derived from the GRFM mosaics, helped to eliminate non-wetland areas from the classification process.

Before proceeding with the classification process, it was necessary to define a classification scheme. Since it was necessary to map the lakes in two seasons, we defined three classes: open water, water + vegetation, and terrestrial areas. At the low-water stages the images were classified as open water and terrestrial areas, because of the limited influence of standing floating vegetation [26]. At high-water the images were classified as open water, water + vegetation, and terrestrial areas because the lakes in this period were covered with aquatic vegetation. This determination was very tricky because it was assumed that standing water, under terrestrial vegetation in the wetland, would not be classified as a lake if there was wood vegetation standing year round above water.

After applying the wetland mask, images segmentation was carried out in both low- and high-water data sets. Segmentation was applied according to previous research [24] [27], which demonstrated that region-based classification of images provides better results than pixel based approaches.

The SPRING segmentation algorithm is based on a region-growing algorithm in which regions are grown from individual pixels and interactively merged according to similarity and minimum area thresholds set by the analyst. If the mean difference in DNs (Digital Numbers) between adjacent pixels or sets of pixels is less than the similarity threshold, the pixels are set to the same region. In this study, preliminary tests were applied so as to select the best thresholds at both low- and high-water mosaics as input for the segmentation. After the segmentation, an interactive clustering algorithm based on Mahalanobis' distance was applied to the segmented images [28]. The preliminary classes were edited to correct misclassified features. 
After mapping the lakes, the next step was to carry out a lake shape classification. To do this, we adopted [14] classification based on the classical lake taxonomy proposed by [29]. Thus, four classes of lacustrine morphology were defined: circular/elliptical, elongated, composite, and dendritic. The F-index [30]-[32] was calculated to obtain the degree of irregularity of the perimeter of the lake, and to determine how this factor relates to morphology categories [14].

The results obtained from image processing were the following maps: 1) lake morphology map at low-water; 2) lake morphology map at high-water; 3) lake morphology/size changes between two different river stages-low and high. Using these results a series of statistics were produced and analyzed.

\section{Results}

The results of this paper are of two natures: technical results which are presented to justify the adopted approach, and lake morphology statistics which will be discussed in more detail.

All classes (open water, aquatic macrophytes and flooded woodland) showed some degree of misclassification because their reflectance and L-HH backscattering responses were similar (Figure 2). It is important to point out that the hydrological data demonstrated similar conditions between the field work period (February), when these photographs were acquired, and the high-water image acquisition (August). In general, as shown

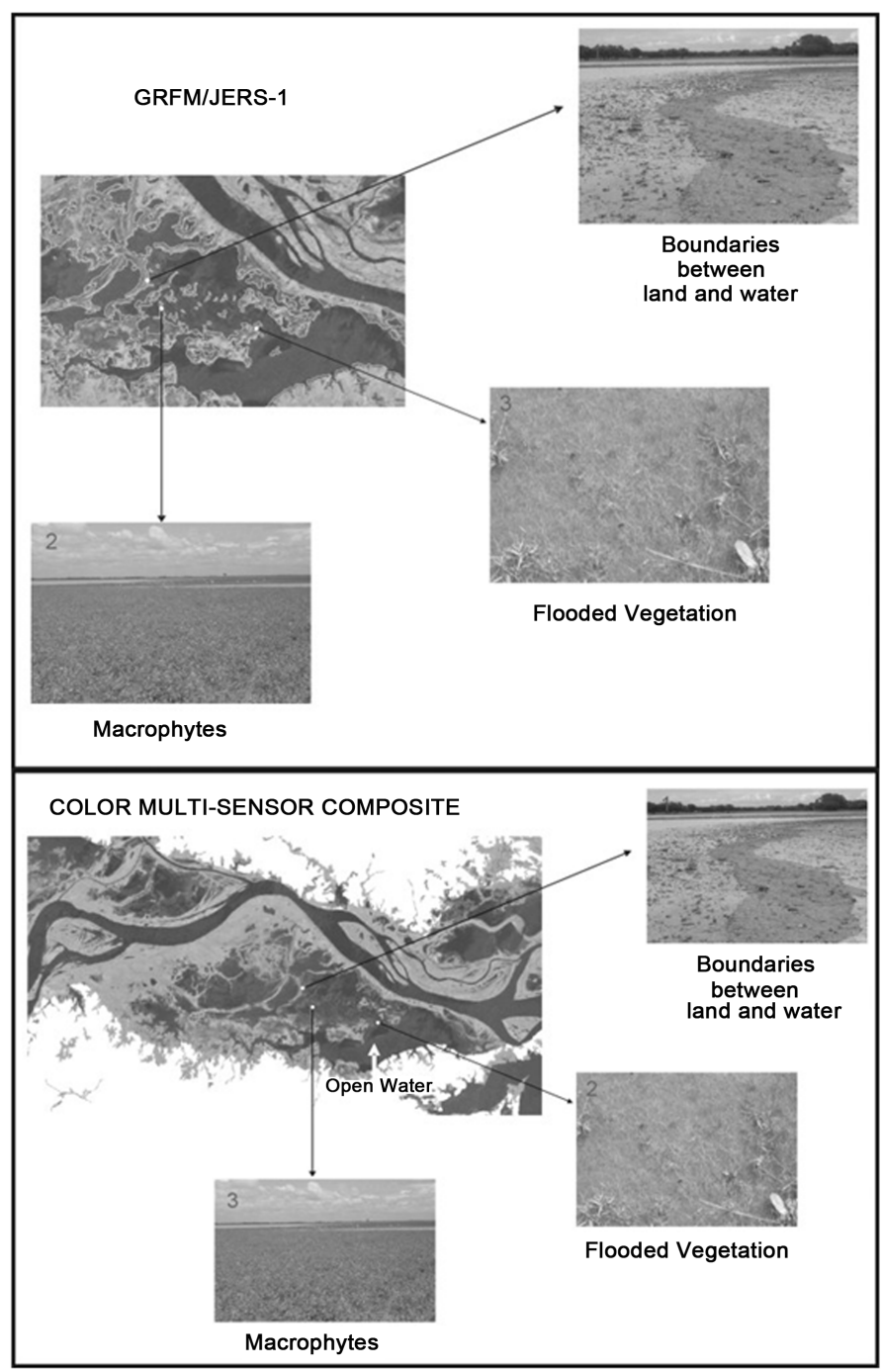

Figure 2. Open water, aquatic macrophytes and flooded woodland classes in the GRFM/ JERS-1; multisensor false color composite SAR-L (G), MOD09-1 (R) and MOD09-2 (B). 
in Figure 2, the open water and vegetation classes were well discriminated in the multisensor false color composite SAR-L (G), MOD09-1 (R) and MOD09-2 (B). In this color composite it is possible to identify the boundaries between land and water, flooded vegetation, and macrophytes. In addition, in more complex areas, the open water class is better discriminated at near infrared band (MOD09-2) than in the multisensor color composite. The strong water absorption band and the high vegetation scattering in the near infrared provide excellent vegetation/water discrimination.

In order to synthesize the changes between the low and high water, a change detection map was built for the entire study area (Figure 3). In this map one can see the main mapped classes: river, lakes and non-water and the expansion area between the two seasons.

Table 3 and Figure 4 show the area occupied by the mapped classes: rivers, lakes and non-water. Figure 5 shows the percentage of each class at each season. The results presented in this table show that the lake classes increase from the low- to high-water period $18.38 \%\left(1152.45 \mathrm{~km}^{2}\right)$, due to the seasonal dynamic influence of the Amazon River. Table 3, Figure 4 and Figure 5 show that from low water to high water the river class area remains relatively stable. It is worthwhile to mention that this class corresponds only to the Amazon River. The irregular distribution of the precipitation on the Amazon floodplain explains this aspect. The major tributaries record the annual flood peak at different periods [33]. The non-water area changed 7.7 percent. The increase in the non-water class during the low-water period was due to the decrease in the lakes class area in the same period.

Table 4 presents the number of lakes and the area for each morphological class derived from the color multisensor composites for both low and high water. The total number of lakes in the study area decreased from low-water to high-water. This change occurred because of the proximity of the smaller individual lakes which, during the high-water collapsed into larger lakes.

Figure 6(a) and Figure 6(b) present the lakes morphological classes' distribution according to the number of lakes and area $\left(\mathrm{km}^{2}\right)$, at both low and high periods. As Figure 6(a) shows, the biggest decrease occurs in the circular/elliptical class, which drops to 210 lakes $\left(132 \mathrm{~km}^{2}\right)$ from low to high water. The analysis of these fig-

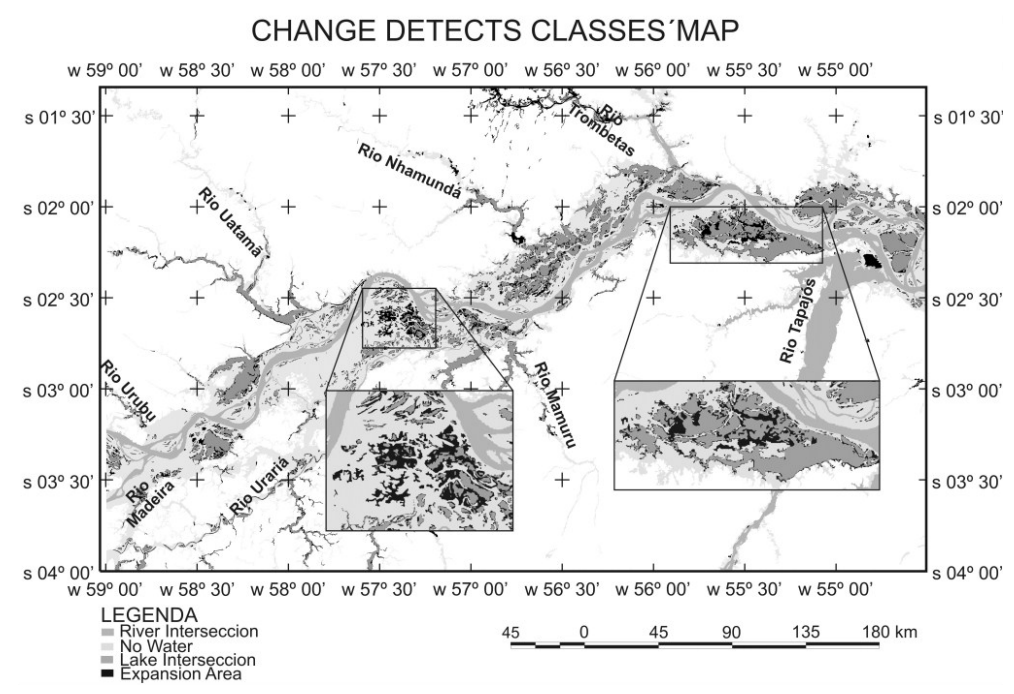

Figure 3. Change detects classes map.

Table 3. Area occupied by the mapped classes.

\begin{tabular}{ccccc}
\hline Classes & Area $\left(\mathrm{km}^{2}\right)$ High-water & Area $(\%)$ High-water & Area $\left(\mathrm{km}^{2}\right)$ Low-water & Area $(\%)$ Low-water \\
\hline Non-Water & 16298.87 & 57 & 17556.63 & 61 \\
Rivers & 6186.88 & 21 & 6081.57 & 21 \\
Lakes & 6267.73 & 22 & 5115.28 & 18 \\
Total & 28753.48 & 100 & 28753.48 & 100 \\
\hline
\end{tabular}




\section{Area occupied by the mapped classes}

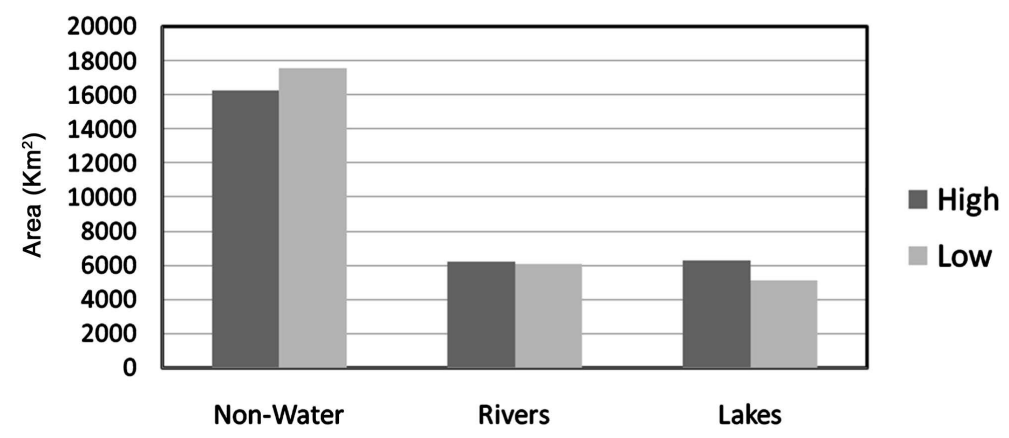

Figure 4. Area occupied by the mapped classes.

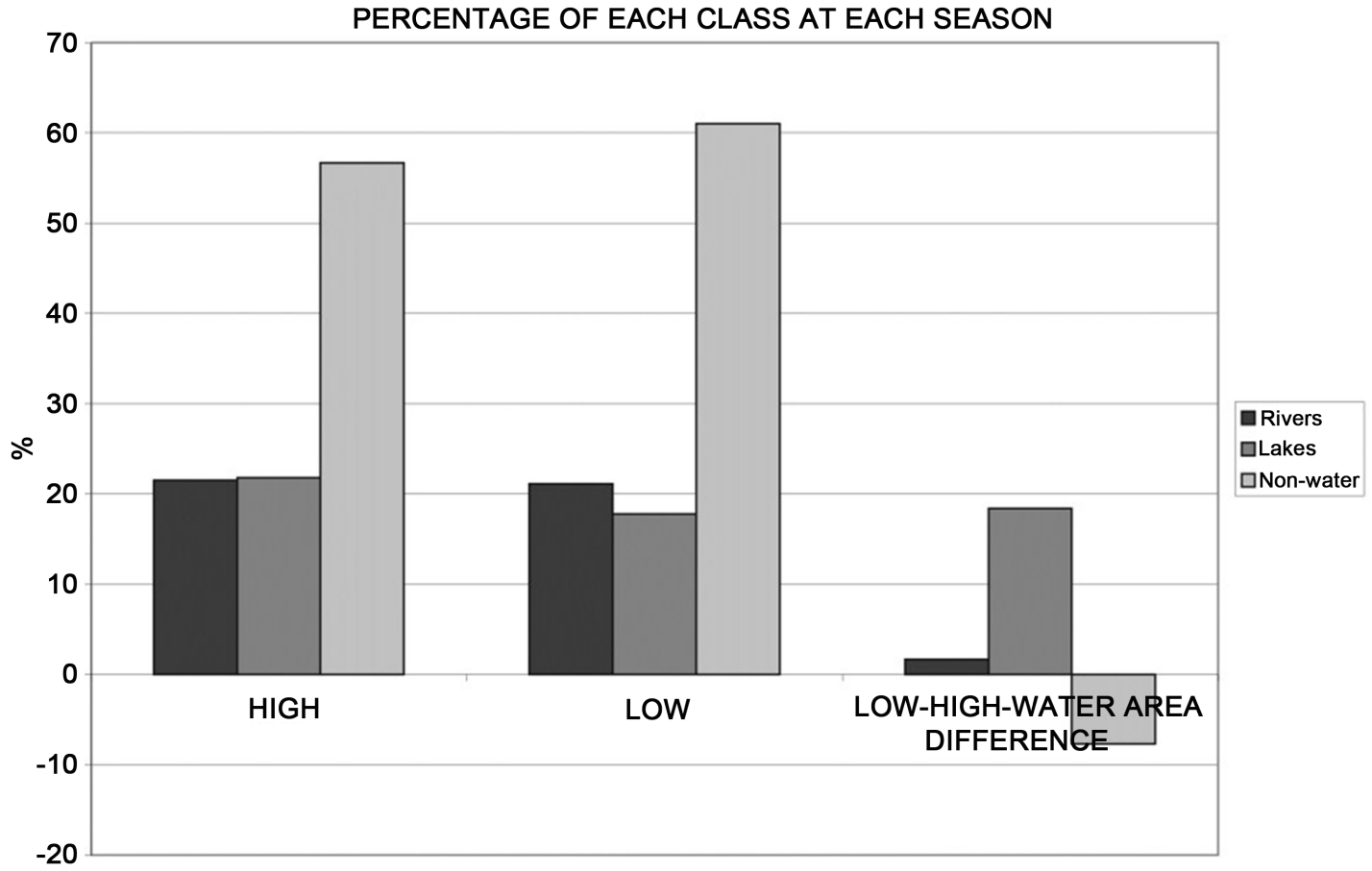

Figure 5. Percentage of each class at each season.

Table 4. Number of lakes and area for each lakes morphological class.

\begin{tabular}{ccccc}
\hline Lakes Morphological Class & $\begin{array}{c}\text { Number of lakes } \\
\text { High-water }\end{array}$ & Area $\left(\mathrm{km}^{2}\right)$ High-water & $\begin{array}{c}\text { Number of lakes } \\
\text { Low-water }\end{array}$ & $\begin{array}{c}\text { Area }\left(\mathrm{km}^{2}\right) \\
\text { Low-water }\end{array}$ \\
\hline Circular/Elliptcal & 880 & 1479.72 & 1090 & 1347.79 \\
Elongated & 80 & 324.56 & 97 & 564.27 \\
Composite & 74 & 1082.11 & 64 & 942.08 \\
Dendritic & 28 & 3381.34 & 21 & 2261.14 \\
TOTAL & 1062 & 6267.73 & 1272 & 5115.28 \\
\hline
\end{tabular}

ures confirms that the circular/elliptical lakes increase in area and decrease their total number during high water. Furthermore, it is possible to verify that the relationship between the area and the number of lakes is not proportional, mainly for dendritic lakes, which are few in number (Figure 6(a)), but occupy more than $50 \%$ of 


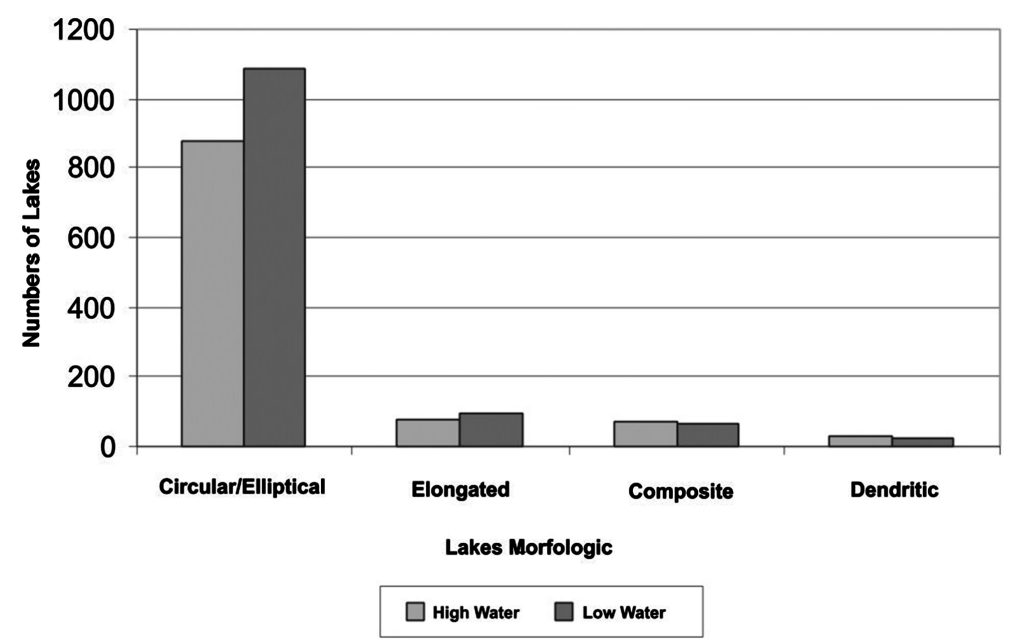

(a)

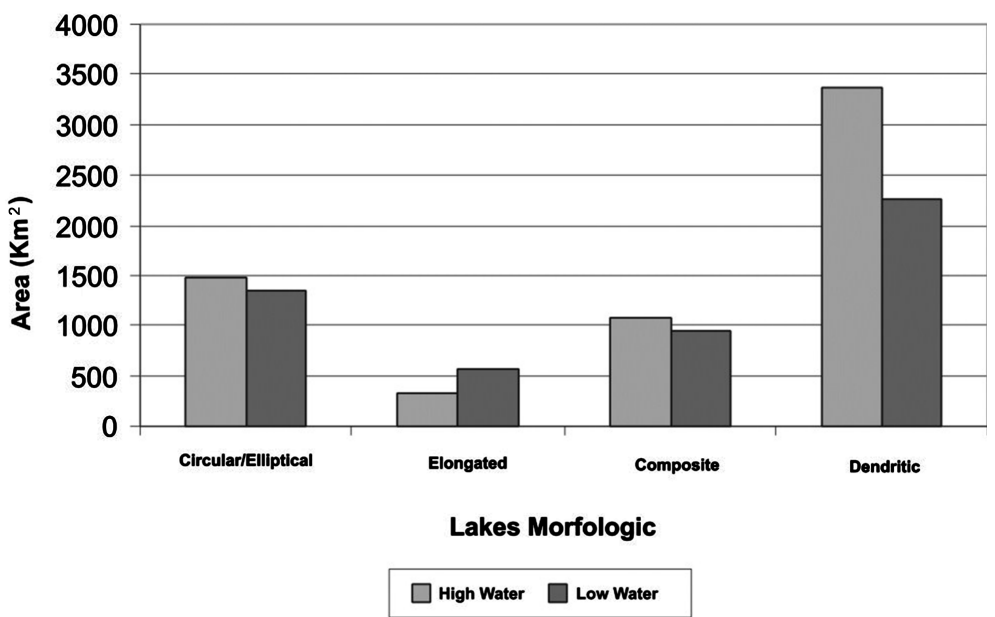

(b)

Figure 6. (a) Lakes morphological class distribution according to the number of lakes; (b) Lakes morphological class distribution according to the area.

the study area during the high-water (Figure 6(b)). According to [12] this kind of lake occupies $65 \%$ of the Amazon floodplain. On the other hand, the circular/elliptical lakes are larger in number but occupy a smaller area.

Near the Madeira River confluence, small size circular/elliptical lakes are predominant because sedimentation processes, related to high discharge of sediments, were intense since the Madeira's River basin contributes around $50 \%$ of the total suspended sediment load transported by the main Amazon channel [1] [34]. On the other hand, towards the Tapajós River confluence, large, extensive lakes of dendritic format are predominant. This can be explained by Obidos' narrowing of the river channel acting as a natural barrier to the sediment upstream.

A series of perpendicular transects of $50 \mathrm{~km}$ in length show this trend in Figure 7(a) and Figure 7(b). Figure 7(a) shows that near the Madeira River confluence there is a small variation in the lakes' area during low-water, from Sample 1 to Sample 2, only $16 \mathrm{~km}^{2}$ of difference. The same phenomenon was verified during the highwater (Figure 7(b)). Between these samples there is a difference of $38 \mathrm{~km}^{2}$. Downstream Madeira River, towards the Tapajós River confluence, the lake area showed a tendency to increase. For example, from sample two to three the increase was from 192.5 to $240 \mathrm{~km}^{2}$ at low and high-water, respectively.

\section{Discussion}

The larger classification mistakes occurred in the transition areas, between open water and inundated vegetation 
Low Water

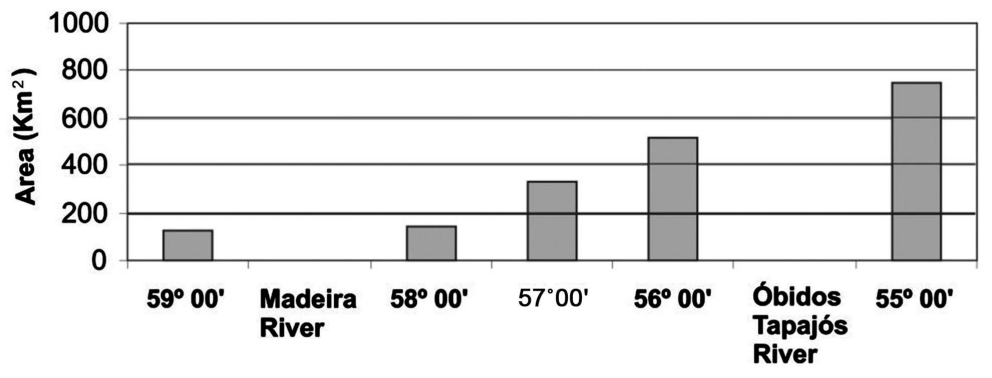

Longitude

(a)

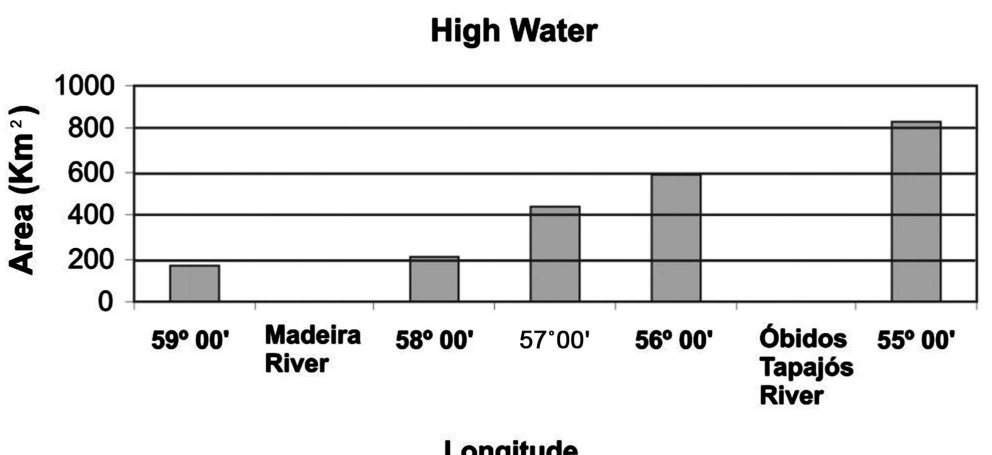

(b)

Figure 7. (a) Variation in the lakes' area during low-water; (b) Variation in the lakes' area during high-water.

(macrophytes). Besides the constrains of the remote sensing image used, the dynamic change between land and water in floodplains makes it difficult to differentiate between aquatic and terrestrial organisms because many of them show adaptations to both environments [35].

This analysis is even more complicated because many herbaceous plants occupy an intermediate position between terrestrial and aquatic plants. They begin to grow on the dry lake bottom at low water taking up nutrients from the sediments. When the water level rises, they continue to grow in water up to $10 \mathrm{~m}$ deep taking up huge amounts of dissolved nutrients from the water by adventitious roots on the nodes. When the water recedes, they are stranded on the drying lake bottom, decompose, and release the nutrients to the dry sediments where the nutrients are taken up by plants that can grow there during the terrestrial phase [35].

It is important to point out that due to the spatial resolution of the products used and the thresholds applied in the classification process, the statistics obtained in this study were restricted to lakes with an area superior to $0.01 \mathrm{~km}^{2}$. The degradation of the image spatial resolution affected the results of the lake morphology assessment [32]. The number of lakes mapped decreased from 1131 to 176, degrading the spatial resolution from $12 \mathrm{~m} \times 12$ $\mathrm{m}$ to $100 \mathrm{~m} \times 100 \mathrm{~m}$. They verified that there was a non-proportional relationship between lake area and number of lakes in the floodplain region. With respect to the lake classes, most of the changes were verified in circular/elliptical and elongated lakes, which were reduced to $90.4 \%$ and $85.45 \%$, respectively.

The results obtained in this study confirm that the difference in size and shape of lakes in the Amazon floodplain is due to the variation in the intensity of the sedimentation processes, which is greatly affected by structural controls. The high production of sediments in its basin can explain the smaller lakes near the Madeira River confluence. Structural arches promoting entrenchment of the river as it passes through zones of deformation and subsidence along major faults and the smaller discharge of sediments [36]. At Óbidos Narrows the Amazon River channel is over $2 \mathrm{~km}$ wide and $60 \mathrm{~m}$ deep [37]. The largest lakes are just downstream from Óbidos and the area is as much as $65 \mathrm{~km}$ across [14]. The along-stream pattern in the number of lakes is also irregular. It increases after the Madeira River confluence and then the lakes disappear just downstream from the Tapajós River [1]. 
The expansion of lakes classes' area, which is a consequence of the flood pulses, greatly influences the other wetland ecosystems generally with a high biodiversity importance and high bio-productivity [35]. This phenomenon and other aspects analyzed in this study were all readily observable in the satellite images utilized because in these images they are enhanced, making them easier to distinguish, despite the constraints of this data.

\section{Conclusions}

The results obtained in this study showed that from low to high water the lakes area increased but the number of lakes diminished. In the study area the circular/elliptical lakes comprised the biggest area, followed by elongated, composite, and dendritic, respectively, for both low- and high-water periods. The increasing area of the lakes due to the Amazon River seasonal dynamic was $18 \%$.

The best results were obtained with the multitemporal and multi-sensor data analysis approaches. They showed that images used were able to detect the relationship between the morphologic lakes and the sediments discharged from the Amazon River. Despite the constraints, the multi-sensor images were able to map the lake system of the Amazon floodplain for both low- and high-water periods.

Further investigations to clearly define the actual effectiveness using SAR data as the basis for a regionalscale operational program to study and monitor wetlands are necessary. The new opportunities will be open with the dual-polarization radar system onboard the Japanese Advanced Land Observing Satellite (ALOS), successor of the JERS-1 and ALOS/PALSAR data. The systematic repetitive acquisition strategy during this satellite's lifetime may effectively contribute to this type of research.

\section{References}

[1] Mertes, L.A.K., Dunne T. and Martinelli, L.A. (1996) Channel Floodplain Geomorphology along the Solimões-Amazon River, Brazil. Geological Society of America Bulletin, 108, 1089-1107. http://dx.doi.org/10.1130/0016-7606(1996)108<1089:CFGATS >2.3.CO;2

[2] Campbell Jr., K.E., Frailey, C.D. and Pittman, L.R. (2006) The Pan-Amazonian Ucayali Peneplain, Late Neogene Sedimentation in Amazonia, and the Birth of the Modern Amazon River System. Palaeogeography, Palaeoclimatology, Palaeoecology, 239, 166-219. http://dx.doi.org/10.1016/j.palaeo.2006.01.020

[3] Latrubesse, E.M. and Franzinelli, E. (2002) The Holocene Alluvial Plain of the Middle Amazon River, Brazil. Geomorphology, 44, 241-257. http://dx.doi.org/10.1016/S0169-555X(01)00177-5

[4] Latrubesse, E.M. and Franzinelli, E. (2005) The Late Quaternary Evolution of the Negro River, Amazon, Brazil: Implications for Island and Floodplain Formation in Large Anabranching Tropical Systems. Geomorphology, 70, 372397. http://dx.doi.org/10.1016/j.geomorph.2005.02.014

[5] Franzinelli, E. and Igreja, H.L.S. (2002) Modern Sedimentation in the Lower Negro River, Amazonas State, Brazil. Geomorphology, 44, 259-271. http://dx.doi.org/10.1016/S0169-555X(01)00178-7

[6] Franzinelli, E. and Igreja, H.L.S. (1990) Utilização de Sensoriamento Remoto na interpretação da Area do baixo Rio Negro e Grande Manaus. Proceedingsof the 6th Brazilian Remote Sensing Symposium, 3, 641-648.

[7] Sternberg, H.O. (1950) Vales tectônicos na planície amazônica? Revista Brasileira de Geografia, 12, 513-533.

[8] Forsberg, B.R., Hashimoto, Y., Roseqvist, A. and Miranda, F.P. (2000) Tectonic Falt Control of Wetland Distributions in the Central Amazon Revealed by JERS-1 Radar Imagery. Quaternary International, 72, 61-66. http://dx.doi.org/10.1016/S1040-6182(00)00021-5

[9] Almeida Filho, R. and Miranda, F.P. (2007) Mega Capture of the Rio Negro and Formation of the Anavilhanas Archipelago, Central Amazônia, Brazil: Evidences in an SRTM Digital Elevation Model. Remote Sensing of Environment, 110, 387-392. http://dx.doi.org/10.1016/j.rse.2007.03.005

[10] Franzinelli, E. and Latrubesse, E. (1993) Neotectonic in the Central Part of the Amazon Basin. INQUA-Neotecton, 16, 10-13.

[11] Sternberg, H. (1987) Aggravation of Floods in the Amazon River as a Consequence of Deforestation. Geografiska Annaler, 69A, 201-219. http://dx.doi.org/10.2307/521378

[12] Sippel, S.J., Hamilton, S.K. and Melack, J.M. (1992) Inundation Area and Morphometry of Lakes on the Amazon River Floodplain. Archiv für Hydrobiologie, 123, 385-400.

[13] Mertes, L.A.K., Daniel, D.L., Melack, J.M., Nelson, B., Martinelli, L.A. and Forsberg, B.R. (1995) Spatial Patterns of Hydrology, Geomorphology and Vegetation on the Floodplain of the Amazon River in Brazil from a Remote Sensing Perspective. Geomorphology, 13, 215-232. http://dx.doi.org/10.1016/0169-555X(95)00038-7 
[14] Melack, J.M. (1984) Amazon Floodplain Lakes: Shape, Fetch and Stratification. Verhandlungen Internationale Vereinigung für Theoretische und Angewandte Limnologie, 22, 1278-1282.

[15] Melack, J.M., Hess, L.L. and Sippel, S. (1994) Remote Sensing of Lakes and Floodplains in the Amazon Basin. Remote Sensing Review, 10, 127-142. http://dx.doi.org/10.1080/02757259409532240

[16] Arraut, E.M., Rudorff, C.M., Barbosa, C.C.F., Carvalho, J.C., Filho, W.P. and Novo, E.M.L.M. (2005) Estudo do comportamento espectral da Clorofila e dos Sólidos em Suspensão nas águas do Lago Grande de Curuai (Pará), na época da seca, através de técnicas de Espectroscopia de Campo. Proceedings of XII Simpósio Brasileiro de Sensoriamento Remoto, Goiânia, 16-21 April 2005, 2447-2454.

[17] Lewis, A.J. and Henderson, F.M. (1998) Radar Fundamentals: The Geoscience Perspective. In: Hendesron, F.M. and Lewis, A.J., Eds., Principles and Application of Imaging Radar: Manual of Remote Sensing, 3th Edition, Hendesron and Lewis, New York, 567-629.

[18] Gonzaga, E.G., Gonçalves, E.T.T. and Coutinho, L.E.C. (2000) Petroleum Geology of Amazon Basin, Brazil: Modelin of Hydrocarbon Generation and Migration. In: Mello, M.R. and Katz, B.J., Eds., Petroleum System of South America Margins, Vol. 73, 159-178.

[19] Tassinari, C.C.G. and Macambira, M.J.B. (1999) Geochronological Provinces of Amazonian Craton. Episodes, 22, 174-182.

[20] Assumpção, M. and Suárez, G. (1988) Source Mechanisms of Moderate-Size Earthquakes and Stress Orientation in Mid-Plate South America. Geophysical Journal, 92, 253-267. http://dx.doi.org/10.1111/j.1365-246X.1988.tb01138.x

[21] Iriondo, M. and Suguio, K. (1981) Neotectonic of the Amazon Plain. Bulletin of the INQUA Neotectonic Commission, 4, 72-78.

[22] Silva, G.G. (1976) Folha SA-21 Santarém. Projeto RADAM, 10, 21-196..

[23] Sioli, H. (1984) Hydrochemistry and Geology in the Brazilian Amazon Region. Amazoniana, 1, 74-83.

[24] Hess, L.L., Melack, J.M., Novo, E.M.L.M., Barbosa, C.C.F. and Gastil, M. (2003) Dual-Season Mapping of Wetland Inundation and Vegetation for the Central Amazon Basin. Remote Sensing of Environment, 87, 404-428. http://dx.doi.org/10.1016/j.rse.2003.04.001

[25] Rosenqvist, A., Shimada, M., Chapman, B. and Freeman, A. (2000) The Global Rain Forest Mapping Project: A Review. International Journal of Remote Sensing, 23, 1201-1234.

[26] Costa, M. (2000) Net Primary Productivity of Aquatic Vegetation of the Amazon Floodplain: A Multi-SAR Satellite Approach. Ph.D. Thesis, University of Victoria, Victoria.

[27] Barbosa, C., Hess, L., Melack, J. and Novo, E.M.L.M. (2000) Mapping Amazon Basin Wetlands through Region Growing Segmentation and Segmented-Based Classification JERS-1 Data. Proceedings of IX Simposio Latino Americano de Percepcion Remota y Sistemas de Informacion Espacial, Puerto Iguazú, 6-10 November 2000, 1165-1176.

[28] Bins, L.S., Fonseca, L.M.G., Erthal, G.J. and Mitsuo II, F. (1996) Satellite Imagery Segmentation: A Region Growing Approach. Proceedings of VII Simposio Brasileiro de Sensoriamento Remoto, Salvador, 14-19 May 1996, 677-680.

[29] Hutchinson, G.E. (1951) A Treatise on Limnology. John Wiley \& Sons, London.

[30] Straskraba, M. and Gnauck, A. (1982) Aquatische Okosysteme: Modellierung und Simulation. Gustav Fischer Verlag, Stuttgart.

[31] Sperling, E.V. (1999) Morfologia de lagos e represas. DesaUFMG, Belo Horizonte.

[32] França, A.M.S. (2005) Aplicação de Sensoriamento Remoto no estudo da influência da dinâmica sazonal do rio Amazonas sobre a morfologia dos sistemas lacustres. Master's Thesis, INPE, São José dos Campos.

[33] Junk, W.J. (1983) As águas da Bacia Amazônica. In: Salati, E., Junk, W.J., Shubart, H.O.R. and Oliveira, A.E., Eds., Amazônia: desenvolvimento, integração e ecologia, Brasiliense, São Paulo, 45-100.

[34] Latrubesse, E.M., Stevaux, J.C. and Sinhá, R. (2005) Tropical Rivers. Geomorphology, 70, 187-206. http://dx.doi.org/10.1016/j.geomorph.2005.02.005

[35] Junk, W.J. (1997) The Central Amazon Floodplain-Ecology of a Pulsing System. Springer, New York, 525. http://dx.doi.org/10.1007/978-3-662-03416-3

[36] Meade, R.H., Dunne, T., Richey, J.E., Santos, U.M. and Salati, E. (1985) Storage and Remobilization of Suspended Sediment in the Lower Amazon River of Brazil. Science, 228, 488-490. http://dx.doi.org/10.1007/978-3-662-03416-3

[37] Baker, V.R. (1986) Fluvial Landforms. In: Short, N.M. and Blair Jr., R.W., Eds., Geomorphology from Space, NASA, Washington, 255-315. 
Scientific Research Publishing (SCIRP) is one of the largest Open Access journal publishers. It is currently publishing more than 200 open access, online, peer-reviewed journals covering a wide range of academic disciplines. SCIRP serves the worldwide academic communities and contributes to the progress and application of science with its publication.

Other selected journals from SCIRP are listed as below. Submit your manuscript to us via either submit@scirp.org or Online Submission Portal.
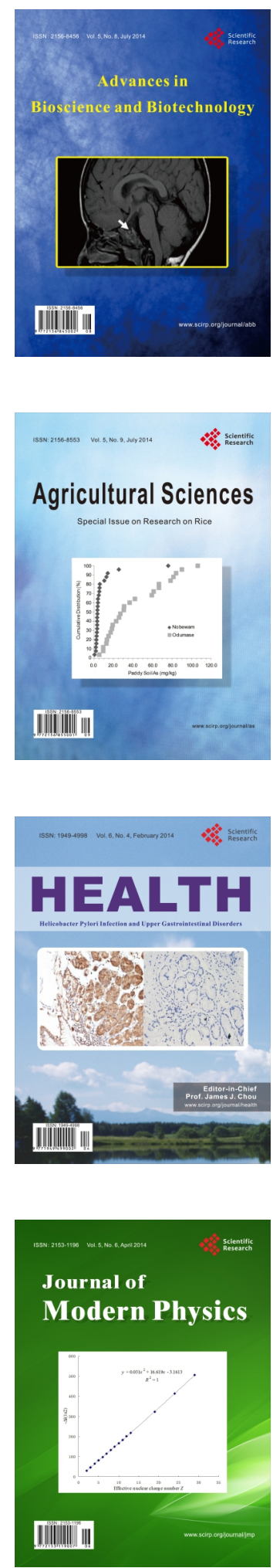
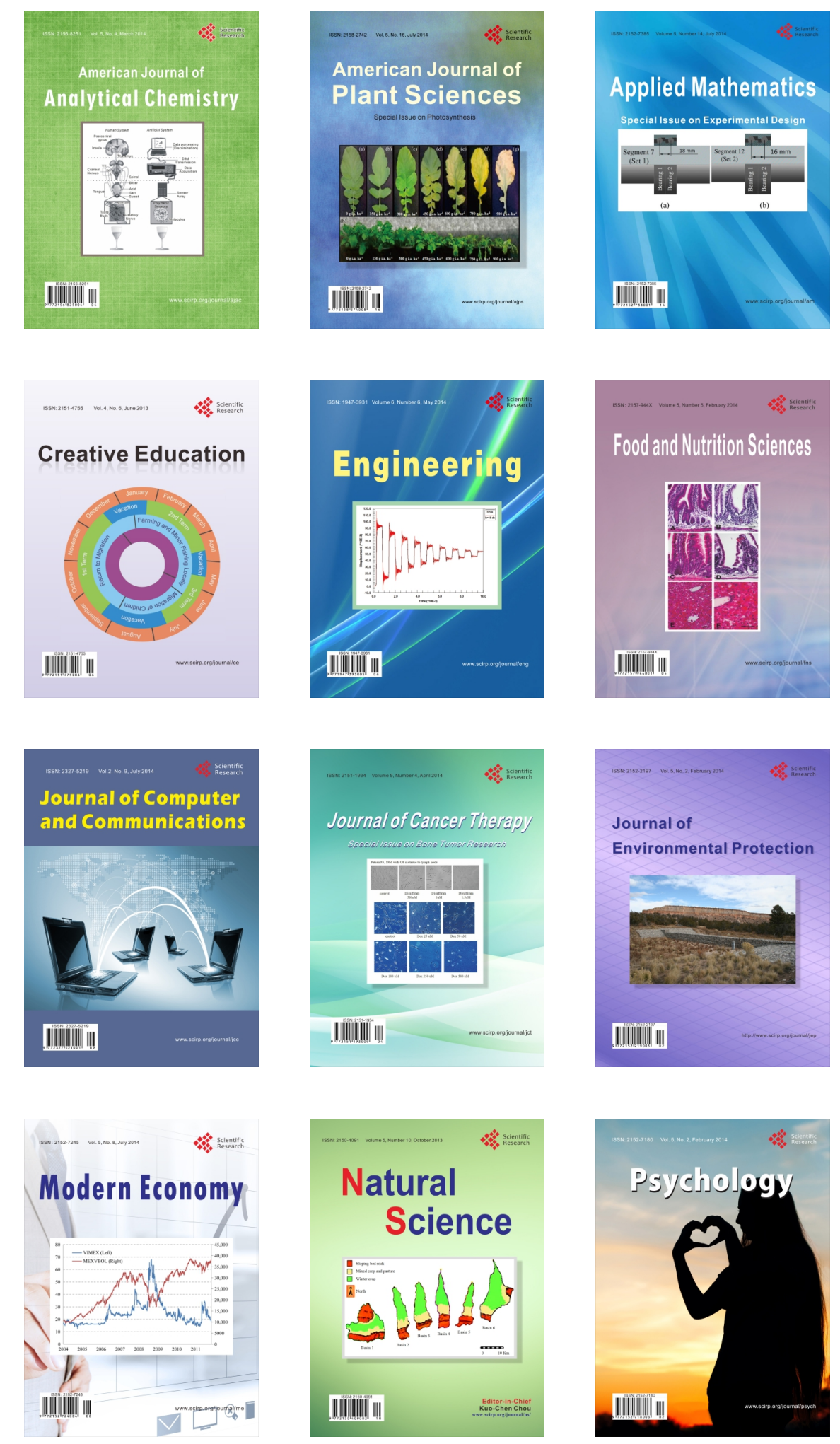